\title{
DEVELOPMENT OF WOODCERAMICS FROM TROPICAL FLORA**
}

\author{
ITSAREE HOWPINJAI ${ }^{*}$, NIKHOM LAEMSAK² AND PONGSAK HENGNIRAN² \\ ${ }^{1}$ Department of Silviculture, Faculty of Forestry, Kasetsart University, Bangkok 10900, Thailand \\ ${ }^{2}$ Department of Forest Products, Faculty of Forestry, Kasetsart University, Bangkok. 10900, Thailand
}

Received 14 December 2018 / Accepted 23 January 2019

\begin{abstract}
Woodceramics are porous carbon or hybrid materials, derived from woody materials impregnated with a thermosetting resin and vacuum carbonized at a high temperature. Woodceramics have become commercially valuable as these are used in many appliances such as heaters, gas filters, absorbents, humidity and temperature sensors. Hence, this study aimed to determine the suitable conditions for producing woodceramics from various materials and their potential applications. The Specific Surface Area (SSA), pore volume, pore diameter, and adsorption isotherm of woodceramics made from Bamboo, Pine, Eucalyptus, Rubberwood and Oil Palm shell particleboards were obtained using the Brunauer-Emmett-Teller (BET) method. The average pore diameter is classified as being mesoporous $(2-50 \mathrm{~nm})$. The SSA and adsorption isotherm results of the woodceramics made from Eucalyptus showed that these species can be used as an activated charcoal and their volume electrical resistivity is similar to that of a semiconductor. When carbonized at maximum temperatures of $800{ }^{\circ} \mathrm{C}$ and $1,000{ }^{\circ} \mathrm{C}$, the electromagnetic shielding effectiveness (ESE) of woodceramics was approximately $20-60 \mathrm{~dB}$ within a frequency range of $800-2,200 \mathrm{MHz}$. This ESE was higher than that woven from boron carbon fiber, carbon boron, and stainless steel fiber filled thermoplastics. Moreover, the woodceramics production cost was lower than that of using the commercial materials.
\end{abstract}

Keywords: adsorption isotherms, electromagnetic shielding, Specific Surface Area, volume electrical resistivity, woodceramics

\section{INTRODUCTION}

Woodceramics are porous carbon/carbon composites or hybrid materials, made from woody and lignocellulosic materials impregnated with thermosetting resin such as phenolic resin and vacuum carbonized at a high temperature (Yu et al. 2012). Woodceramics are accepted as environmentally benign materials, as these are produced from woody materials or lignocellulosic industrial waste. Their advantage over other materials is that these are not only produced from wastes, but also are stronger and resistant to higher temperatures compared to the original carbonaceous material. During carbonization, the raw materials, wood or

\footnotetext{
${ }^{*}$ Corresponding author, e-mail: h.itsaree@gmail.com

**This paper was presented at the $3^{\text {rd }}$ International Conference on Tropical Biology 2018, 20-21 September 2018, Bogor, West Java, Indonesia
}

woody material, change into soft amorphous carbon and the impregnated phenolic resin changes into hard glassy carbon. The pores, which originally existed in the wood and woody material, still remain in the woodceramics. Accordingly, woodceramics are amorphous carbon and glassy carbon porous composite materials which possess multifunctional properties and perform like advanced fiber reinforced composites.

Woodceramics are known to have high stiffness, high corrosiveness, friction resistance, electrical resistivity, electromagnetic shielding ability and high temperature resistance. These properties are useful in the production of heaters, gas filters, humidity and temperature sensors, catalyst carriers, friction materials, and electromagnetic shielding materials (Pan et al. 2013). 
Hence, the properties of woodceramics derived from carbonized Eucalyptus (Eucalyptus spp.), Rubberwood (Hevea brasiliensis), Pine (Pinus spp.), Bamboo (Dendrocalamus spp.) and Oil Palm shell particleboard (Elaeis guineensis Jacq.) impregnated with phenolic resin were investigated. The effects of the raw materials, the maximum temperature and the heating rate on the specific surface area (SSA), adsorption isotherms, the electrical resistivity and the electromagnetic shielding effectiveness of woodceramics were analyzed.

\section{MATERIALS AND METHODS}

\section{Sample Preparation}

The 5-year-old Eucalyptus and bamboo trees located in the Prachinburi Province, 30-year old Pine trees in Chiang Mai Province and 30-year old Rubberwood trees from Chonburi Province were chosen for this study. The trees were cut into lumber with a dimension of $120 \times 120 \times 12$ $\mathrm{mm}$. All the samples were oven dried at $105^{\circ} \mathrm{C}$ for 24 hours.

The Oil Palm shells were extraction residues obtained from a factory in Chonburi Province. The shells were ground to a size of $0.355-2.00$ $\mathrm{mm}$. The ground Oil Palm shells (OPS) were mixed with phenolic resin powder in a ratio of 10:1 by weight. The mat so obtained was pressed, at a pressure of 150 psi and a temperature of $150{ }^{\circ} \mathrm{C}$ for $10 \mathrm{~min}$, to obtain the oil palm shell particleboard (OPS-PB).

\section{Impregnation Process}

The samples were impregnated with a commercial phenolic resin, with a specific gravity of 1.081 and viscosity of 30.7 centipoise, produced by the Thai GCI Resitop Company Limited. All samples were placed in an impregnating vacuum chamber, evacuated with a vacuum pressure of $75 \mathrm{mmHg}$, and held for 2 hours. A $30 \%$ solid content of phenolic resin was added to the chamber as the vacuum pressure was released. To obtain further impregnation, the samples were immersed in the phenolic resin for 4 hours at room temperature. The samples were then removed from the chamber and wiped of excess impregnate.

\section{Carbonization Process}

The five materials (Eucalyptus, Rubberwood, Pine, Bamboo and oil palm shell particleboard) were impregnated with the phenolic resin, and carbonized at a temperature of 600,800 and $1,000{ }^{\circ} \mathrm{C}$ in a vacuum furnace with a vacuum time of 2 hours and $2 \mathrm{~L} / \mathrm{min}$ of nitrogen feed rate at a maximum temperature, and heating rates of 1,5 and $10{ }^{\circ} \mathrm{C} / \mathrm{min}$. Five replications for each batch of carbonization process were then tested.

\section{RESULTS AND DISCUSSION}

\section{Specific Surface Area (SSA)}

The specific surface area property of woodceramics indicates its usage for gas filters, humidity and temperature sensors, catalyst carriers etc.). The SSA of woodceramics made from Bamboo, Pine, Eucalyptus, Rubberwood and Oil Palm shell particleboard was determined using the Brunauer-Emmett-Teller (BET) method, after being carbonized at $800{ }^{\circ} \mathrm{C}$ at a heating rate of $5^{\circ} \mathrm{C} / \mathrm{min}$.

Table 1 Specific Surface Area, pore volume and average pore diameter of woodceramics derived from various raw materials

\begin{tabular}{lccc}
\hline Raw material & SSA area $\left(\mathrm{m}^{2} / \mathrm{g}\right)$ & $\begin{array}{c}\text { Pore volume } \\
\left(\mathrm{cm}^{3} / \mathrm{g}\right)\end{array}$ & $\begin{array}{c}\text { Average pore diameter } \\
(\mathrm{nm})\end{array}$ \\
\hline Bamboo & 4 & 0.012 & 4.96 \\
Pine & 10 & 0.018 & 11.75 \\
Eucalyptus & 27 & 0.034 & 6.49 \\
Rubberwood & 10 & 0.017 & 2.95 \\
OPS-PB & 65 & 0.048 & 6.84 \\
\hline
\end{tabular}


In this study, the SSA of Eucalyptus $\left(27 \mathrm{~m}^{2} / \mathrm{g}\right)$ was similar to that obtained by Pan et al. (2013) for woodceramics derived from sugarcane bagasse $\left(33 \mathrm{~m}^{2} / \mathrm{g}\right)$, after being carbonized at $800{ }^{\circ} \mathrm{C}$. Table 1 also shows that the SSA of woodceramics derived from Bamboo is $4 \mathrm{~m}^{2} / \mathrm{g}$ and Oil Palm shell particleboards is $65 \mathrm{~m}^{2} / \mathrm{g}$.

The range of woodceramics pore volume made from Bamboo, Pine, Eucalyptus, Rubberwood and Oil Palm shell particleboard was $0.012-0.048 \mathrm{~cm}^{3} / \mathrm{g}$, which is low when compared with other materials. The pore volume of bagasse char $\left(0.17 \mathrm{~cm}^{3} / \mathrm{g}\right)$ was similar to the pore volume of woodceramics made from Bamboo $\left(0.012 \mathrm{~cm}^{3} / \mathrm{g}\right)$, Pine $\left(0.018 \mathrm{~cm}^{3} / \mathrm{g}\right)$ and Rubberwood $\left(0.017 \mathrm{~cm}^{3} / \mathrm{g}\right)$. The pore volumes of woodceramics made from Eucalyptus (0.034 $\left.\mathrm{cm}^{3} / \mathrm{g}\right)$ and Oil Palm shell particleboards $(0.048$ $\mathrm{cm}^{3} / \mathrm{g}$ ) were higher than that of other materials.

The average pore diameter (APD) from Pine woodceramics was the highest $(11.75 \mathrm{~nm})$ followed by that of the woodceramics made from Oil Palm shell particleboard $(6.84 \mathrm{~nm})$, then of Eucalyptus (6.49 nm), Bamboo (4.96 nm) and of Rubberwood $(2.95 \mathrm{~nm})$ which had the lowest APD. These APDs were classified as mesoporous (2-50 nm).

\section{Adsorption Isotherms}

An adsorption isotherm is the relationship between the amount of gas adsorbed per unit mass of adsorbent at a constant pressure and temperature. The shape of the adsorption isotherm will provide information on adsorption process and gas-adsorption capacity of the adsorbent surface. $\mathrm{N}_{2}$ was rapidly adsorbed onto the woodceramics and it was observed that the adsorption isotherms of woodceramics from Pine, Eucalyptus, Rubberwood and Oil Palm shell particleboard were similar (Table 1). These complied with Type IV interference, Type VI isotherms, which is attributable to a monolayer- multilayer adsorption as it follows a path similar to a Type II isotherm, obtained from a given adsorptive on the same surface area of the adsorbent in a non-porous form. The adsorption isotherms obtained for Pine, Eucalyptus, Rubberwood and Oil Palm shell particleboard were similar to that of the woodceramics obtained from chicken waste carbonized at $800{ }^{\circ} \mathrm{C}$.

The adsorption isotherm of Bamboo was classified as Type VI, in which the sharpness of the steps depends on the system and the temperature. The stepwise multilayer adsorption on a uniform non-porous surface was found to be similar to the adsorption isotherms of woodceramics from sugarcane bagasse (Pan et al. 2013). The gas-adsorption capacity of woodceramics from Bamboo was $7.7 \mathrm{cc} / \mathrm{g}$. The maximum adsorption capacity $(30.2 \mathrm{cc} / \mathrm{g})$ was obtained by Oil Palm shell particleboard, while the lowest capacity was measured for woodceramics made from Bamboo $(7.7 \mathrm{cc} / \mathrm{g}$.)

The SSA and gas adsorption capacity of woodceramics from Eucalyptus and Oil Palm shell particleboard are a function of active carbon (Huang et al. 2012). The SSA, pore diameter, pore volume and gas-adsorption properties also depend on the structure of raw materials and the carbonization temperature (Huang et al. 2012).

The values of SSA $\left(64.71 \mathrm{~m}^{2} / \mathrm{g}\right)$ and pore volume $\left(0.048 \mathrm{~cm}^{3} / \mathrm{g}\right)$ of woodceramics made from Oil Palm shell particleboard were higher than those of other materials used in the study. The average pore diameter of woodceramics from Pine $(11.75 \mathrm{~nm})$ was larger than those woodceramics from other materials.

Different woodceramics showed different adsorption properties, SSA, pore diameter and pore volume, depending on the starting material and carbonization temperature. The SSA and adsorption isotherm of woodceramics from Eucalyptus was affected by the activated carbon. 

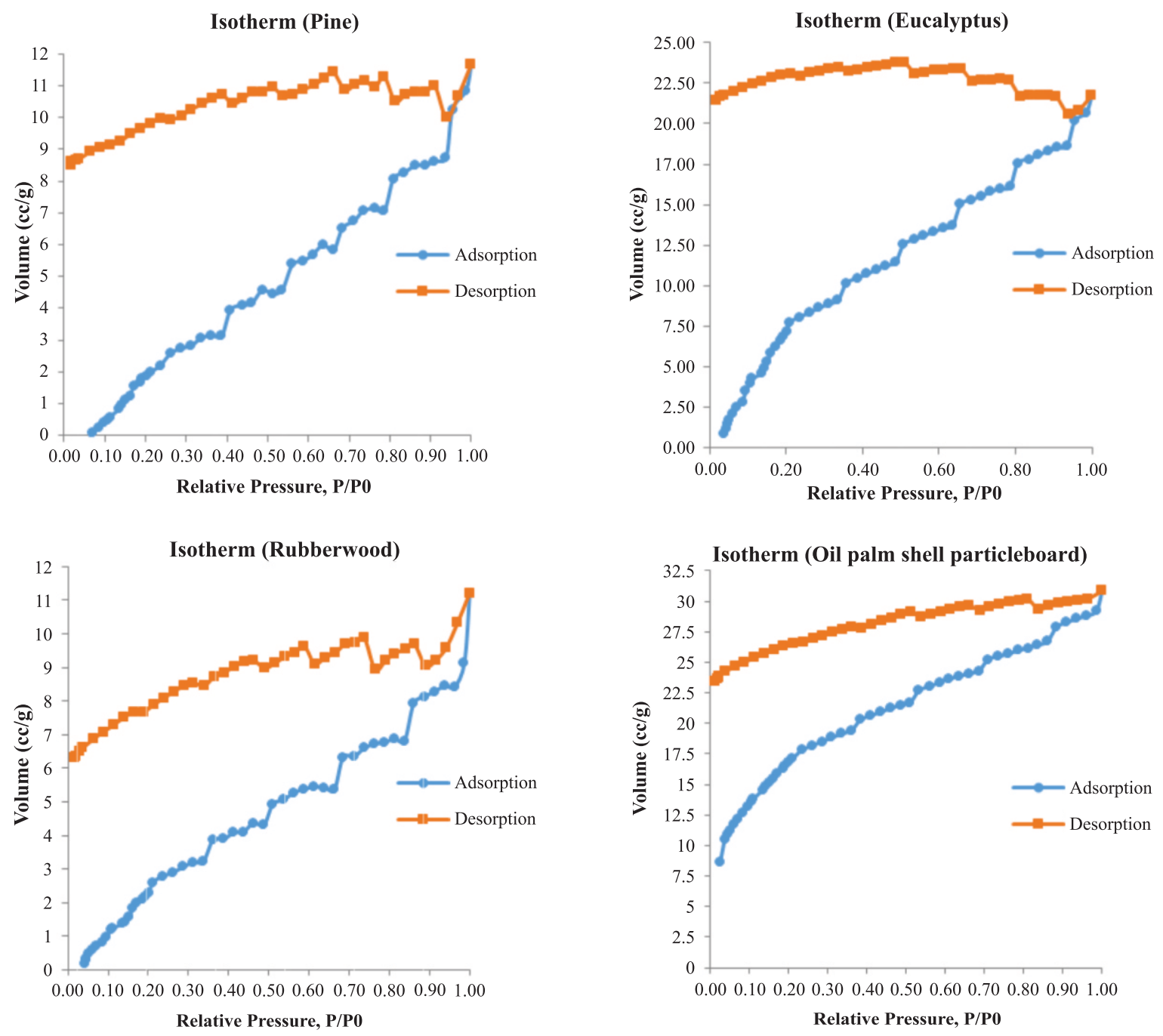

Isotherm (Bamboo)

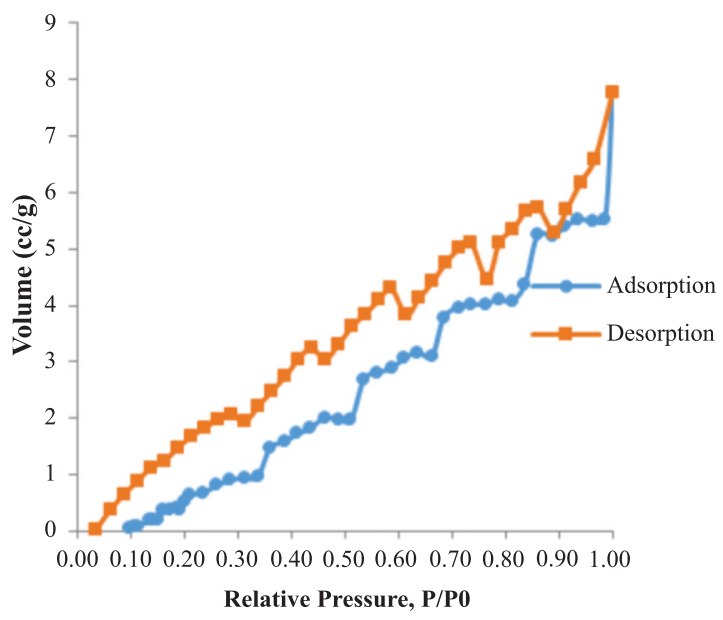

Figure 1 Adsorption-Desorption isotherm of the various woodceramics carbonized at $800{ }^{\circ} \mathrm{C}$ at a heating rate of $5{ }^{\circ} \mathrm{C} / \mathrm{min}$ 


\section{Volume Electrical Resistivity (VER)}

The volume electrical resistivity (VER) of a woodceramics depends on two factors: 1) the space of carbonized wood (The number of contact points decreases with the increase of carbonization temperature resulting in a high contact resistivity) and 2) the changes in structure of phenolic compound during carbonization process, which causes a decrease in the volume of woodceramics electrical resistivity. A higher heating rate results in a faster decay rate of the wood chemical compound, the porosity and space between glassy carbon and amorphous carbon increases, leading to a decrease in the VER ( $\mathrm{Yu}$ et al. 2012).

The volume of woodceramics electrical resistivity made from Bamboo, Pine, Eucalyptus, Rubberwood and Oil Palm shell particleboard decreased with the increasing maximum carbonization temperature (Table 2). The volume electrical resistivity of the woodceramics, obtained from carbonization at $600{ }^{\circ} \mathrm{C}$, was significantly higher than that at $800{ }^{\circ} \mathrm{C}$ and at $1,000{ }^{\circ} \mathrm{C}$. The phenolic compound caused a big structural change during the woodceramics production at a high carbonization temperature, resulting in a rapid decrease of VER (Rhim et al. 2010). The VER of woodceramics, carbonized at the heating rate of 1 and $10{ }^{\circ} \mathrm{C} / \mathrm{min}$, was higher than that of woodceramics carbonized with the heating rate of $5{ }^{\circ} \mathrm{C} / \mathrm{min}$. The VER from Bamboo and Pine were the lowest. Lastly, the raw materials, the maximum carbonization temperature, and the heating rate played an important role in determining the volume electrical resistivity of the woodceramics.

\section{Electromagnetic Shielding Effectiveness (ESE)}

A lower volume electrical resistivity was beneficial to improve the electromagnetic shielding of woodceramics. Hence, the volume electrical resistivity of the woodceramics product carbonized at a heating rate of $5{ }^{\circ} \mathrm{C} / \mathrm{min}$ was evaluated for frequencies range of 8003,000 $\mathrm{MHz}$, which are classified as ultra-high frequencies (UHF) and is widely used in cellular systems, broadband wireless network, radio, television, and others following the standards of the National Broadcasting and Telecommunications Commission, Thailand (NBTC).

Table 2 Effects of raw materials, maximum carbonization temperatures and heating rates on the volume electrical resistivity (VER) of woodceramics

\begin{tabular}{ccccccc}
\hline \multicolumn{2}{c}{ Condition } & \multicolumn{5}{c}{$\begin{array}{c}\text { Volume electrical resistivity } \\
(\Omega . \mathrm{cm})\end{array}$} \\
\hline $\begin{array}{c}\text { Max } \\
\begin{array}{c}\text { temperature } \\
\left({ }^{\circ} \mathrm{C}\right)\end{array}\end{array}$ & $\begin{array}{c}\text { Heating } \\
\text { rate } \\
\left({ }^{\circ} \mathrm{C} / \mathrm{min}\right)\end{array}$ & Bamboo & Pine & Eucalyptus & Rubberwood & OPS-PB \\
\hline 600 & 1 & $(4.00 \pm 0.21) \times 10^{4}$ & $(3.02 \pm 0.14) \times 10^{5}$ & $(3.17 \pm 0.11) \times 10^{6}$ & $(4.27 \pm 0.33) \times 10^{6}$ & $(3.94 \pm 0.40) \times 10^{5}$ \\
& 5 & $(7.62 \pm 0.44) \times 10^{5}$ & $(5.22 \pm 0.07) \times 10^{5}$ & $(3.230 \pm 0.19) \times 10^{5}$ & $(2.20 \pm 0.08) \times 10^{5}$ & $(8.52 \pm 0.44) \times 10^{5}$ \\
& 10 & $(2.08 \pm 0.13) \times 10^{5}$ & $(5.68 \pm 0.28) \times 10^{5}$ & $(2.74 \pm 0.29) \times 10^{5}$ & $(3.44 \pm 0.28) \times 10^{5}$ & $(5.51 \pm 0.11) \times 10^{6}$ \\
\hline 800 & 1 & $18.4 \pm 0.19$ & $25.2 \pm 0.15$ & $17.0 \pm 0.23$ & $12.1 \pm 0.14$ & $11.2 \pm 0.14$ \\
& 5 & $7.21 \pm 0.09$ & $11.3 \pm 0.04$ & $8.44 \pm 0.39$ & $11.3 \pm 0.12$ & $8.54 \pm 0.42$ \\
& 10 & $6.67 \pm 0.74$ & $11.9 \pm 0.06$ & $9.94 \pm 0.56$ & $10.3 \pm 0.06$ & $14.5 \pm 0.19$ \\
\hline 1000 & 1 & $3.10 \pm 0.20$ & $4.78 \pm 0.19$ & $4.23 \pm 0.19$ & $4.89 \pm 0.18$ & $5.38 \pm 0.15$ \\
& 5 & $2.67 \pm 0.15$ & $4.35 \pm 0.21$ & $3.93 \pm 0.25$ & $4.52 \pm 0.25$ & $5.43 \pm 0.14$ \\
& 10 & $2.74 \pm 0.12$ & $6.46 \pm 0.35$ & $3.62 \pm 0.17$ & $4.33 \pm 0.17$ & $6.26 \pm 0.34$ \\
\hline
\end{tabular}




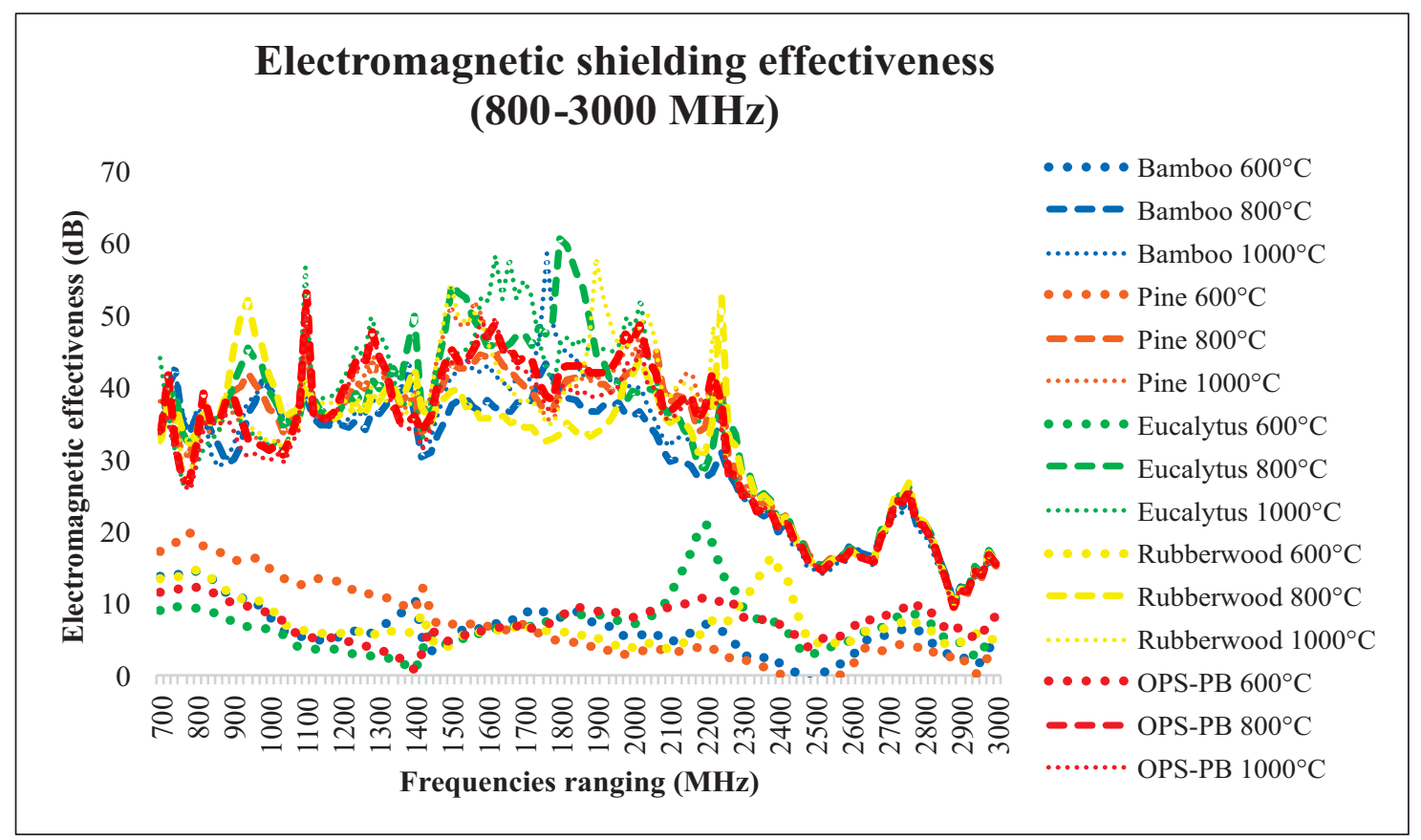

Figure 2 Electromagnetic shielding effectiveness for frequencies range of $800-3,000 \mathrm{MHz}$ of woodceramics carbonized at a heating rate of $5^{\circ} \mathrm{C} / \mathrm{min}$

The electromagnetic shielding effectiveness (ESE) increased with the increasing maximum temperature. The ESE of woodceramics made at a maximum temperature of $600{ }^{\circ} \mathrm{C}$ was very poor, especially in a frequency range of 1,5003,000 $\mathrm{MHz}$ (Fig. 2). The ESE values of woodceramics made at maximum temperatures of $800{ }^{\circ} \mathrm{C}$ and $1,000{ }^{\circ} \mathrm{C}$ were acceptable (higher than $20 \mathrm{~dB}$ ), in a frequency range of $700-2,200 \mathrm{MHz}$.

Increasing the maximum carbonization temperature has resulted in an increased (ESE). This was due to the decay velocity of chemical elements that made up the woodceramics. The higher the temperature, the higher the porosity of woodceramics, the better is the efficiency of the electromagnetic shielding. The porous structure of a woodceramics helps to absorb electromagnetic waves (Mistik et al. 2012). The woodceramics made at maximum temperatures of $800{ }^{\circ} \mathrm{C}$ and $1,000{ }^{\circ} \mathrm{C}$, within a frequency range of $700-2,200 \mathrm{MHz}$, have higher electromagnetic shielding effectiveness than that of fabrics woven from boron carbon fiber and carbon boron. It has a protection efficiency of about $20-50 \mathrm{~dB}$ at frequencies range of $800-$ 3,000 MHz. At $950 \mathrm{MHz}$, the protection performance of woodceramics, carbonized at $800{ }^{\circ} \mathrm{C}$ and $1,000{ }^{\circ} \mathrm{C}$, is comparable to that of the stainless steel fiber filled thermoplastics (36-42 dB) (Mistik et al. 2012).

The suitable conditions for producing woodceramics for electromagnetic shielding material was that of Pine wood carbonized at $800{ }^{\circ} \mathrm{C}$ with a heating rate of $5{ }^{\circ} \mathrm{C} / \mathrm{min}$, as this resulted in a woodceramics that can be used in a wider frequency spectrum (NBTC 2017) (Table 3).

Table 3 Suitable conditions for producing woodceramics from Bamboo, Pine, Eucalyptus, Rubberwood and Oil Palm shell particleboard for electromagnetic shielding applications (Classified using the frequency range of NBTC, Thailand)

\begin{tabular}{ccc}
\hline Frequency range $(\mathrm{MHz})$ & Applications & Suitable condition \\
\hline $800-960$ & Cellular system, Trunked mobile radio system & Pine $800{ }^{\circ} \mathrm{C}=35.3 \mathrm{~dB}$ \\
$970-1,210$ & Aeronautical radio navigation & Pine $800{ }^{\circ} \mathrm{C}=35.3 \mathrm{~dB}$ \\
$1,220-1,420$ & Radio location, Radar & Pine $1,000{ }^{\circ} \mathrm{C}=32.5 \mathrm{~dB}$ \\
$1,520-1,700$ & Radio Astronomy & Pine $1,000{ }^{\circ} \mathrm{C}=33 \mathrm{~dB}$ \\
$1,710-2,170$ & Mobile Phone & Eucalyptus and $\mathrm{OPS}-\mathrm{PB} 1,000{ }^{\circ} \mathrm{C}=41.4 \mathrm{~dB}$ \\
$2,300-2,690$ & Broadband wireless access & Rubberwood $1,000{ }^{\circ} \mathrm{C}=16 \mathrm{~dB}$ \\
$2,700-3,000$ & Aeronautical Radio Service, radio navigation & Oil Palm shell particleboard $800{ }^{\circ} \mathrm{C}=14 \mathrm{~dB}$ \\
\hline
\end{tabular}




\section{CONCLUSION}

The commercial properties of woodceramics depend on the raw materials, the maximum temperature and the heating rate. The suitable woodceramics production processes of Eucalyptus, Bamboo, Rubberwood, Pine and Oil Palm shell particleboard depend on its specific purpose or application. The conditions present during the woodceramics production affect the SSA and adsorption isotherms, electrical resistivity and electromagnetic shielding. The average pore diameters of woodceramics made from Bamboo, Pine, Eucalyptus, Rubberwood, and Oil Palm shell particleboard at $800{ }^{\circ} \mathrm{C}$ are classified as mesoporous $(2-50 \mathrm{~nm})$. The volume electrical resistivity of woodceramics made at a maximum carbonization temperatures of $800{ }^{\circ} \mathrm{C}$ and $1,000{ }^{\circ} \mathrm{C}$ was between 2.6 and $25.2 \Omega . \mathrm{cm}$ indicating that these woodceramics are semiconductors. The electromagnetic shielding effectiveness of these woodceramics carbonized at temperatures of $800{ }^{\circ} \mathrm{C}$ and $1,000{ }^{\circ} \mathrm{C}$ was higher than those of commercial materials woven from boron carbon fiber, carbon, and stainless steel fiber filled thermoplastics. Suitable conditions for the production of woodceramics for electromagnetic shielding material is the carbonization of Pine wood at $800{ }^{\circ} \mathrm{C}$ at a heating rate of $5{ }^{\circ} \mathrm{C} / \mathrm{min}$. Hence, the woodceramics produced from the study can be used in a wide range of frequencies.

\section{ACKNOWLEDGEMENTS}

This research was funded by the Center for Advanced Studies in Tropical Natural
Resources, Institute of Advanced Studies, Kasetsart University (CASTNaR, NRU-KU), Thailand.

\section{REFERENCES}

Huang ZK, Lu QF, Lin Q, Cheng X. 2012. Microstructure, properties and lignin-based modification of wood-ceramics from rice husk and coal tar pitch. J Inorg Organomet Polym Mater 22:1113-21.

Mistik SI, Sancak E, Usta I, Kocak ED, Akalin M. 2012. Investigation of electromagnetic shielding properties of boron and carbon fibre woven fabrics and their polymer composites. In: $4^{\text {th }}$ RMUTP International Conference: Textiles \& Fashion. Proceedings: 2012 July 3-4. Bangkok (TH): Rajamangala University of Technology Phra Nakhon (RMUTP) and the Technical University of Liberec (TUL). p. 34.

Pan J, Cheng X, Yan X, Zhang C. 2013. Preparation and hierarchical porous structure of biomorphic woodceramics from sugarcane bagasse. J Eur Ceram Soc 33:575-81.

Rhim YR, Zhang D, Rooney M, Nagle DC, Fairbrother DH, Herman C, Drewry DG III. 2010. Changes in the thermophysical properties of microcrystalline cellulose as function of carbonization temperature. Carbon 48:31-40.

The Office of National Broadcasting and Telecommunications Commission (NBTC) [Internet]. 2015. National table of frequency allocation. [updated 2015; cited 2017 Nov 1]. Available from: https://house.nbtc.go.th/wps/ $\mathrm{wcm} /$ connect/NBTC/NTFA+2558+unofficial $+\mathrm{t}$ ranslation-17092558.pdf

Yu XC, Sun DL, Sun DB, Xu ZH, Li XS. 2012. Basic properties of woodceramics made from bamboo powder and epoxy resin. Wood Sci Technol 46:23-31. 